Jurnal Kesmas Asclepius

Volume 1, Nomor 1, Juni 2019

e-ISSN : 2684-8287

p-ISSN : 2656-8926

DOI: https://doi.org/10.31539/jka.v1i1.575

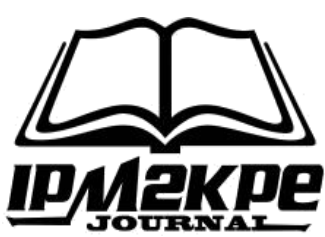

\title{
ANALISIS PERNIKAHAN USIA DINI DI KABUPATEN BENGKULU TENGAH TAHUN 2017
}

\author{
Bintang Agustina Pratiwi ${ }^{1}$, Wulan Angraini ${ }^{2}$, Padila $^{3}$, Nopiawati ${ }^{4}$, Yandrizal $^{5}$ \\ Universitas Muhammadiyah Bengkulu ${ }^{1,2,3,4,5}$ \\ bintang170887@gmail.com ${ }^{1}$
}

\begin{abstract}
ABSTRAK
Penelitian ini bertujuan untuk mengetahui penyebab kejadian pernikahan usia dini di Kabupaten Bengkulu Tengah. Penelitian ini menggunakan pendekatan kualitatif dengan mewawancarain informan sebanyak 7 orang menggunakan teknik purposive sampling di Kabupaten Bengkulu Tengah. Selanjutnya informasi yang didapat dianalisis. Informan menikah dini dikarenakan tidak adanya aktifitas lain setelah tamat sekolah, tidak memahami dampak dari menikah dini, ingin mempunyai teman hidup, tidak menjadi beban orang tua, adanya dorongan orang tua. Media komunikasi digunakan Informan sebagai alat komunikasi, untuk menentukan waktu berkencan. Faktor lingkungan menjadi alasan informan menikah dini, anggapan menikah di usia dini hal yang biasa. Simpulan, Pernikahan usia anak terjadi disebabkan oleh terhentinya pendidikan, faktor ekonomi, tidak mau menjadi beban orang tua, kurangnya pengetahuan tentang dampak menikah di usia anak, serta tidak adanya aktifitas lain setelah putus sekolah.
\end{abstract}

Kata Kunci : Lingkungan, Media, Orang Tua, Pengetahuan, Pernikahan Usia Dini

\begin{abstract}
This study aims to determine the causes of early age marriage in Bengkulu Tengah Regency. This study used a qualitative approach by interviewing 7 informants using purposive sampling technique in Bengkulu Tengah Regency. Furthermore, the information obtained is analyzed. The informant married early due to the absence of other activities after finishing school, did not understand the impact of early marriage, wanted to have a life partner, did not become a burden on parents, and encouraged parents. Communication media used by informants as a means of communication, to determine the date of the date. Environmental factors became the reason for informants to marry early, the assumption of getting married at an early age is common. In conclusion, child marriage occurs due to cessation of education, economic factors, not wanting to be a burden on parents, lack of knowledge about the impact of child marriage, and the absence of other activities after dropping out of school.
\end{abstract}

Keywords: Environment, Media, Parents, Knowledge, Early Marriage 


\section{PENDAHULUAN}

Fenomena ledakan penduduk masih terus meningkat di Indonesia, salah satu faktor penyumbang terjadinya ledakan peduduk adalah pernikahan usia dini. Tingginya angka perempuan menikah di usia dini merupakan dampak dari praktik hubungan seksual yang terlalu dini. 8\% wanita umur 25- 49 tahun melakukan hubungan seksual yang pertama pada umur 15 tahun dan $45 \%$ melakukan hubungan seksual yang pertama pada umur 20 tahun. Selain itu lingkungan tempat tinggal juga sangat berpengaruh dalam membentuk perilaku anak. Wanita yang tidak bersekolah lebih aktif secara seksual daripada wanita yang berpendidikan perguruan tinggi, hanya 5-6 \% wanita tidak tamat SD atau tidak sekolah yang tidak pernah melakukan hubungan seksual. Proporsi wanita tidak tamat SMA keatas yang tidak pernah melakukan hubungan seksual sebesar 24\% atau lebih (BKKBN, 2012).

Penelitian yang dilakukan oleh Khaparistia (2015) membuktikan bahwa terdapat beberapa faktor yang menjadi penyebab tingginya angka menikah di usia muda. Faktor utamanya adalah perekonomian yang kurang, faktor pendukung lainnya adalah pengaruh teman sebaya, keinginan dari informan, keluarga, dan hamil di luar nikah, tergolong miskin, pendidikan yang rendah serta tinggal di pedesan.

Di roma praktik pernikahan usia muda terjadi pada perempuan yang mempunyai keluarga miskin, yang memiliki pendidikan kurang, dan yang tinggal di pedesaan. Hasil analisis bivariat menunjukan keputusan untuk sekolah dan menikah dipengaruhi oleh lingkungan dan kebiasaan masyarakat sekitar (Hotchkiss et al., 2016).

Ada hubungan yang kompleks antara perkawinan usia anak dan pendidikan di Indonesia. Anak perempuan yang menikah sebelum usia 18 tahun (pengantin anak) memiliki tingkat pencapaian pendidikan yang lebih rendah dibandingkan dengan anak perempuan yang belum menikah, khususnya setelah sekolah dasar (SD). Selain itu, anak yang menikah lebih muda memiliki pencapaian pendidikan yang lebih rendah dibandingkan dengan anak yang menikah lebih tua. Anak perempuan cenderung tidak melanjutkan sekolah setelah mereka menikah. \%tase perkawinan usia anak perempuan usia 20-24 tahun semakin kecil sejalan dengan meningkatnya capaian pendidikan. \%tase perkawinan usia anak perempuan yang lulus SD (40,5\%) berbeda sangat tajam dengan mereka yang melanjutkan sekolah sampai lulus sekolah menengah atas (5,0 \%). Angkaangka ini menunjukkan bahwa berinvestasi dalam pendidikan sekolah menengah untuk anak perempuan, khususnya untuk menyelesaikan sekolah menengah atas adalah salah satu cara terbaik untuk memastikan anak perempuan mencapai usia dewasa sebelum menikah. Analisis dalam laporan ini juga menunjukkan bahwa perkawinan usia anak sangat terkait dengan kemiskinan, tetapi prevalensi perkawinan usia anak yang tinggi terdapat pada provinsi dengan tingkat kemiskinan yang relatif rendah. Selain kemiskinan, praktik tersebut dapat dipengaruhi oleh faktor-faktor lain, termasuk normanorma sosial dan budaya (BPS, 2015).

Angka usia kawin pertama pada kelompok umur 16-18 tahun sebesar 14,47\%. Angka kelahiran pada kelompok remaja usia 15-19 tahun mencapai 11,8/1.000 kelahiran pada wanita usia subur (BKKBN Prov Bengkulu, 2017). Hasil Riskesdas Provinsi Bengkulu tahun 2010 menunjukan, usia perkawinan pertama perempuan kelompok umur 15-19 tahun di Bengkulu mencapai 45,9\%, angka ini lebih tinggi dari angka rata rata nasional yang sebesar $41,9 \%$, sedangkan usia perkawinan pertama kelompok umur 10 - 14 tahun di Provinsi Bengkulu termasuk tertinggi nomor 6 (enam) se Indonesia yaitu 6,5\% (Kemenkes, 2010). 
Informasi yang diperoleh dari portal berita BKKBN Provinsi Bengkulu (2017), Kabupaten Bangkulu Tengah masuk dalam kategorik 3 besar kasus pernikahan usia dini. Angka tertinggi di Kabupaten Mukomuko 32,83\%, Seluma 30,83\% dan Bengkulu Tengah 29,12\%. Selain itu Sekretaris KPI Bengkulu Irna Riza Yuliastuti pada rangkaian kegiatan anti kekerasan terhadap perempuan di Kabupaten Bengkulu Tengah pada kompas.com mengungkapkan, kasus pernikahan anak berusia 11 tahun terjadi di Kabupaten Bengkulu Tengah. Umur 11 tahun merupakan masa pendidikan di sekolah dasar.

\section{METODE PENELITIAN}

Jenis dari penelitian yang dilakukan adalah penelitian deskriptif kualitatif. Penelitian ini dilakukan di Kabupaten Bengkulu Tengah. Informan kunci pada penelitian ini adalah Kepala Desa yang akan memberikan informasi tentang warganya yang menikah di usia dini. Informan utama adalah remaja yang menikah usia dini dan tokoh agama/tokoh adat. Informan dipilih sesuai dengan konsep pemilihan dalam penelitian kualitatif yaitu kesesuaian dan kecukupan dengan prinsip saturasi. Pemilihan informan menggunakan teknik purposive sampling.

Pengumpulan data dilakukan dengan cara wawancara mendalam yang dilakukan terhadap informan di kediaman informan atau ditempat yang telah ditentukan bersama informan sehingga membuat informan merasa lebih nyaman. Pada kesempatan yang berbeda kemudian peneliti melakukan wawancara terhadap key informan yang terlebih dahulu membuat janji dengan key informan apakah wawancara dilakukan di rumah atau di tempat lain yang dirasakan informan cukup nyaman.

Dalam penelitian ini, peneliti mengunakan model analisis interaksi, dimana komponen reduksi data dan sajian data dilakukan bersamaan proses pengumpulan data. Setelah data terkumpul, maka tiga komponen analaisis (reduksi data, sajian data, penarikan kesimpulan).

\section{HASIL PENELITIAN \\ Faktor Predisposisi \\ Alasan Menikah}

Berdasarkan hasil wawancara mengenai alasan yang mempengaruhi informan memutusakan menikah diusia dini yang dilakukan terhadap informan 1,2 dan 3, berikut adalah pernyataannya:

“...Tidak mau membebani orang tua, tidak ada harapan untuk sekolah...lumayan,meringankan beban orang tua,,, ”(informan 1)

“...takut kehilangan pacar, karna calon juga sudah memaksa mengajak menikah, karna umurnya. aku kan juga cinta dengan dia. Ingin hidup lebih baik, tidak membebani orang tua...mau sekolah juga nggak bisa nggak ada biaya..." (informan 2)

“...Sudah tidak sekolah lagi, Tidak ada kegiatan lagi kemudian pacar ajak menikah yaa setuju aja. Orang tua juga setuju aja...” (Informan 3)

Informan menyatakan memutuskan menikah karena tidak mau membebani orang tua dan tidak mampu pendidikan lagi. Sementara informan 2 dan 3 menyatakan takut kehilangan pacar dan sudah adanya desakkan dari pasangan yang mengajak segera menikah karena usia pasangannya yang sudah memasuki usia cukup menikah. 
Pernyataan informan di atas juga didukung dari hasil wawancara terhadap tokoh masyarakat setempat yaitu bapak kepala desa dan ketua KUA, yang menyatakan sebagai berikut ini:

“...faktor ekonomi, nggak bisa anak melanjutkan pendidikan, dari pada dia nggak sekolah, nggak ada pilihan lain...jadi nikah lebih cepat, mau bekerja apa yang mau diusahakan? Faktor orang tuanya juga, biar nggak bebani orang tua...” (kepala desa)

"...faktor ekonomi, anak itu tidak sekolah, tidak mel manjutkan jenjang pendidikan, dia di kebun dan aktivitasnya sehar-hari di rumah. Eee apa lagi kerja mereka, itulah dia nikah..." (ketua KUA)

Dari hasil wawancara di atas menunjukan, rendahnya perekonomian keluarga informan menyebabkan orang tua tidak mampu membiayai pendidikan anaknya sehingga anak menjadi putus sekolah. Usia informan yang $<18$ tahun membuatnya kesulitan mencari pekerjaan, akibatnya informan hanya berdiam diri di rumah saja tanpa memiliki kegiatan. Keputusan menikah usia anak diambil informan dengan alasan ingin meringankan beban orang tua, diharapkan ketika sudah menikah beban orang tua menjadi berkurang dan perekonomian keluarga dapat dibantu dari pendapatkan yang dihasilkan suami.

\section{Pengetahuan}

\section{Umur Ideal Menikah}

Ditinjau dari pengetahuan informan terkait pernikahan usia dini, diperoleh hasil wawancara sebagai berikut:

“...Kalau nikah usia 14...” (informan 1)

“...Pernikahan umur 18...” (informan 2)

“...Nikah di bawah umur 18 tahun...” (informan 3)

Dari hasil wawancara di atas menunjukan, 2 dari 3 informan menyatakan pernikahan usia anak adalah pernikahan yang dilakukan pada usia <18 tahun atau pernikahan yang dilakukan pada usia 18 tahun, sementara 1 orang informan menyatakan menikah usia anak adalah pernikahan yang dilakukan pada usia 14 tahun.

Tokoh masyarakat setempat yaitu kepala KUA, menyatakan usia pernikahan untuk perempuan dan laki-laki adalah sebagai berikut:

“...dalam undang-undang pekawaninan nomor 1 tahun 74 pernikahan itu boleh dilaksanakan apabila anak itu sudah masuk usia 16 tahun ke atas untuk perempuan, 19 tahun untuk laki-laki... "(ketua KUA)

\section{Dampak Pernikahan Usia Dini}

Mengenai dampak yang timbul akibat pernikahan dini, kutipan jawaban informan dapat dilihat seperti di bawah ini.

"...Pernikahan umur 17 tahun, kalau yang bersangkutan sehat dan secara fisik cukup besar maka pernikahan dini tidak ada dampak negatifnya...” (Informan 1)

“....Usia ideal menikah perempuan 18 tahun dan laki-laki 20 tahun, maka jika di bawah usia itu disebut pernikahan dini, menurut saya yang berdampak hanya masalah ekonomi karena belum ada pekerjaan mapan, kalau dampak kesehatannya tidak ada..." (Informan 2) 
Pernikahan usia dini tidak berdampak pada kesehatan tubuh asal kondisi badan sehat namun berdampak pada ekonomi keluarga dikarenakan belum ada pekerjaan.

\section{Sikap}

Sikap informan tentang menikah usia dini dapat terlihat pada kutipan wawancara di bawah ini.

“...saya setuju, asal memang suka sama suka dan laki-laki nya juga mau bertanggung jawab...” (Informan 1)

"...biasa saja melihat orang menikah dini. Ada teman hidup berdua... nikah itu enak, bisa bantu nyuci baju suami, nyiapin makanan. Dari pada tidak ada kerjaan di rumah..." (Informan 2)

“...wajar saja orang menikah, artinya sudah sampai jodohnya dari pada menolak lamaran nanti tidak ada lagi yang meu melamar kita. Nanti jadi gadis tuo...” (Informan 3)

Berdasarkan wawancara sikap responden tentang pernikahan usia dini menunjukkan menikah dini merupakan hal yang biasa saja, jika sudah menikah ada kawan hidup yang saling membantu dan bertanggung jawab. Jika sudah ada yang melamar jangan di tolak lagi.

Sementara itu hasil wawancara dengan ketua KUA di peroleh informasi, yang dikutip dari hasil wawancara di bawah ini.

"...Umur menikah itu sudah di atur sesuai UU Pernikahan, Jadi jika mereka siap menikah silahkan terlepas dari apapun kondisi yang lain seperti belum kerja, putus sekolah, yang penting kedua belah pihak dan keluarga sepakat dengan keputusannya... "(ketua KUA)

Ketua KUA bersikap untuk mengizinkan informan menikah sesuai dengan UU Pernikahan dan disetujui oleh kedua belah pihak dan keluarga.

\section{Kegiatan Sosialisasi Penyuluhan}

Kegiatan yang dilakukan oleh pihak pemerintah pusat (BKKBN Provinsi Bengkulu) maupun pemerintah daerah (Kecamatan dan KUA) dalam upaya meningkatkan pengetahuan masyarakat mengenai usia pernikahan dan bahaya menikah di usia anak, berikut adalah hasil wawancaranya:

“...kami ada jadwal safari jum'at keliling ketemu dengan imam, ketemu dengan jama'ah, kita sampaikan UU perkawinan, kita ingatkan usia anak menikah jangan kurang dari UU perkawinan, jangan menikah sirih, jangan menikah tidak tercatat..." (ketua KUA).

“...pernah sosialisasi kerja sama dengan KUA menyampaikan mengenai usia minimal pernikahan... saya juga sosialisasi tentang bahaya pernikahan di usia sekolah di sekolah di tingkat SMA"'(sekertaris kecamatan).

"Pernah sosialisasi dari pihak Kecamatan dan BKKBN. Tahun 2016 di sini dibentuk dan launcing kampung $K B$, tapi tidak ada pembinaan lanjutan, cuma kegiatan sistemoni aja, sudah kegiatan, sudaahh, buat laporan ke sini lagi minta tanda tangan, sudah tu selesai. Disitulah permasalahannya, pemerintah pusat dan daerah tidak ada tindak lanjut..." (kepala desa). 
Dari hasil wawancara di atas menunjukan, telah dilakukannya upaya dalam meningkatkan pengetahuan masyarakat melalui kegiatan sosialisasi dari pemerintah pusat dan daerah. Pihak kecamatan pernah melakukan kerja sama dengan KUA dalam mensosialisasikan usia pernikahan, sementara pihak KUA mempunyai kegiatan rutin yaitu safari Jum'at dan telah bekerjasma dengan institusi pendidikan dalam mensosialisasikan bahaya menikah usia anak, bahkan pihak BKKBN Provinsi telah membentuk dan melauncing kampung KB di salah satu daerah Kecamatan Bang Haji, namun untuk kegiatannya tidak dilakukan tindak lanjut sehingga di lapangan masih dijumpai anak yang menikah di usia $<18$ tahun karena informan tidak mengetahui batasan sebaiknya usia pernikahan.

\section{Faktor Pemungkin}

\section{Tempat Hiburan}

Hasil wawancara mengenai akses untuk bertemu dengan pasangan dapat dilihat pada kutipan wawancara di bawah ini.

“...Ketemuan setiap malam, kalau siang telfonan...jalan ke jembatan...”(informan 1)

“...ketemuannya malam aja dari jam 8 sampai setengah 10 jalan-jalan aja, biasanya nongkrog dijembatan..." (informan 2)

Pernyataan informan di atas juga didukung dari hasil wawancara terhadap tokoh masyarakat setempat yang menyatakan sebagai berikut ini:

“...pergaulan bebas malam hari, tengok di jembatan dimana-mana rami nongkrongnongkrong, apalagi pesta, disitulah pertemuannya..." (kepala desa)

“...pergaulan bebas juga disini menentukan, malem biasanya sudah seperti pasar malem, artinya anak-anak waktu itu berkeliaran, keluar, baik remaja putra-putri keluar sampe tengah malam, nampaklah di jembatan dimana-mana ramai nongkrong-nongkrong... kalau ada pesta waih rami sama muda-mudi aja, iya kalau acara muda-mudikan malam harinya..." (ketua KUA)

Dari hasil wawancara di atas menunjukan, informan sering bertemu pasangan pada malam hari untuk berkencan, terdapat tempat hiburan yang biasa dikunjungi informan sebagai lokasi untuk berpacaran yaitu di jembatan, meskipun hanya untuk sekedar nongkrong-nongkrong. Informanpun mengakui waktu berkencan bersama pasangan sering dilakukan sampai dengan pukul setengan sepuluh malam.

Pendapat senada juga disampaikan oleh Bapak Sekcam (Sekertaris Kecamatan) yang menyatakan sebagai berikut:

"...pasti pergaulan juga, hhehe karena terlalu bebas, kebanyakan ya sering inilah...hamil duluan...” (sekertaris kecamatan)

Menurut bapak sekertaris kecamatan, pergaulan anak di Kecamatan Bang Haji ini termasuk bebas, sehingga terjadilah kejadian hamil di luar nikah.

\section{Media Komunikasi} berikut:

Ditinjau dari paparan media komunikasi, diperoleh hasil wawancara sebagai

“...posisinya sudah tau Hp, pacarannya tiba-tiba nggak terkontrol dengan orang tua, terkadang orang tua banyak di kebun jadi nggak bisa monitor...”(sekertaris kecamatan). 
"komunikasi sangat lancar, Hp itulah yang merusak. Mulai dari facebook, kenalkenalan, dan terjadilah..." (kepala desa).

“...SMP SMA disinikan, jadi orang desa-desa lain betemulah di sekolah, perkiraan aku itu juga mempengaruhi, selain itu karna ada hubungan lewat hp, bekawanbekawan ini akhir-akhirya kan ketemu, ya gadis bujang istilah di dalam desa kalau tidak nafsu seperti itu kan berarti orang itu sakit..."(ketua adat).

Dari hasil wawancara di atas menunjukan, keputusan menikah jika ditinjau dari penggunaan handphone oleh anak-anak di Kecamatan Bang Haji, informan dan tokoh masyarakat sekitar menyatakan penggunaan handphone justru dapat memeperlancar komunikasi dan pertemuan informan dengan pasangan ataupun orang yang baru dikenalnya melalui media sosial, sehingga pertemuan tersebut bisa mengarah kepada perbuatan yang tidak baik.

\section{Faktor Pendorong}

\section{Dukungan Orang Tua}

Berdasarkan hasil wawancara yang mendorong seseorang menikah di usia anak yang dilakukan terhadap informan 1, 2 dan 3, diperoleh hasil sebagai berikut:

“...mungkin karena jodoh, heheh. Ingin merasakan jadi ibu rumah tangga, orang tua mau nimang cucu katanya, hehehe..." informan 1

“...Kalau orang tua setuju saja, karena tidak ada lagi kegiatan di rumah. Selain itu menikah bisa mengurangi beban orang tua..." Informan 2

“...Langsung dijawab setuju, ditanya kapan rencana mau nikahnya...” Informan 3

Orang tua langsung menyetujui jika anak meminta untuk menikah karena bisa meringankan beban orang tua. Selain itu orang tua juga sudah mau menimang cucu.

\section{Dukungan Teman}

Hasil wawancara mengenai dukungan teman mengenai keputusan menikah dapat dilihat pada kutipan wawancara berikut.

“...Sepertinya bahagia liat kawan main dengan anaknya, apalagi ketika aku gendong anaknya, jadi mau punya anak juga..." Informan 1

"...lihat temen sudah ada yang menikah, jadi takut nanti jadi perawan tua..." Informan 2

“...Dulu sebelum menikah kawan suka gangguin, nikahlah mau nunggu apa lagi nanti gadis tua..." Informan 3

Kawan memberikan motivasi kepada informan untuk segera menikah, nanti akan menjadi perawan tua jika kelamaan menikah.

Pernyataan informan di atas juga didukung dari hasil wawancara terhadap tokoh masyarakat setempat yaitu ketua KUA dan sekertaris kecamatan, yang menyatakan sebagai berikut ini.

“...kesadaran orang tua tentang masa depan anak itu penting kurang diperhatikan, orang tua tidak care dengan usia dan pendidikan anaknya..." (Ketua KUA)

"...karna terlalu bebas tadi, kebanyakan ya sering inilah, bergaul samo kawankawanyo...udah hamil duluan,..." ( Sekertrais kecamatan)

“...bergaul samo kawan-kawanyo...sudah hamil duluan,...” (Ketua KUA)

“...bergaul sama temen-temennya...sudah hamil duluan...”( Sekertrais kecamatan) 


\section{Peraturan tentang Pernikahan Usia Dini}

Belum adanya peraturan daerah mengenai pernikahan usia dini. Berikut adalah kutipan hasil wawancara.

"kalau kecamatan ngak punya peraturan, kecamatan hanya mempunyai perda wajib baca qur'an, jadi ketika mendaftar menikah kita tes dulu dari segi agamanya termasuk mengaji... selama usia menikah itu tidak melanggar undang-undang, kami secara hukum kami tidak boleh menolok permohonan pencatatan pernikahan, meskipun usia anak kalau yang perempuan 16 tahun satu hari saja lewat, undangundang sudah memerintahkan boleh. Secara administrasi, pasti kami nikahkan kalo sudah sesuai dengan undang-undang perkawinan..."(ketua KUA).

"Belum, tapi kalau nikah belum cukup umur, nggak bisa dikasihkan surat nikahnya, kami suga sudah pernah menyampaikan itu ke masyarakat..." (sekertaris kecamatan)

Dari hasil wawancara di atas, tokoh masyarakat menyatakan belum adanya peraturan daerah mengenai usia pernikahan, pemerintah daerah hanya memiliki perda (peraturan daerah) wajib mengaji, jadi setiap yang mendaftar menikah di KUA terlebih dahulu dites dari segi agamanya termasuk mengaji. Ketua KUA menyatakan tidak akan menghalangi dan tidak bisa menolak pencatatan pernikahan jika sudah memenuhi persyaratan sesuai undang-undang pernikahan.

\section{PEMBAHASAN}

\section{Faktor Predisposisi}

Berdasarkan hasil penelitian yang telah dilakukan, informan memutuskan menikah dengan harapan dapat meringankan beban orang tua, rendahnya perekonomian keluarga mempengaruhi terputusnya kelanjutan pendidikan yang berakibat pada tingkat pendidikan menjadi rendah sehingga informan tidak sekolah dan mengalami kesulitan dalam mencari pekerjaan, informan tidak mempunyai kegiatan dengan kesehariannya hanya dihabiskan di rumah saja. Maka munculah pemikiran akan membebani orang tua jika hanya berdiam diri, untuk itu ia memutuskan untuk menikah, ditambah lagi sudah adanya ajakan dari pasangan untuk menikah. Setara dengan hasil Data Survey Demografi dan Kesehatan Indonesia (2012) yang menyatakan wanita yang tidak bersekolah lebih aktif secara seksual dari pada wanita yang berpendidikan perguruan tinggi (Kemenkes, 2012).

Pendidikan yang dimiliki seseorang erat kaitannya dengan pengetahuan, 2 dari 3 informan menyatakan pernikahan usia anak adalah pernikahan yang dilakukan pada usia $<18$ tahun tanpa menyebutkan berapa rincian yang baik usia perkawinan untuk perempuan dan laki-laki. Sementara undang-undang Nomor 1 tahun 74 tentang pernikahan menyebutkan usia pernikahan untuk anak perempuan adalah 16 dan 19 tahun untuk laki-laki.

Pihak pemerintah baik itu pusat maupun daerah sudah melakukan sosialisasi mengenai usia pernikahan dan bahaya menikah usia dini, ketua KUA menyatakan sudah dilakukannya upaya melalui kerjasama dengan institusi pendidikan untuk mensosialisasikan hal tersebut, bahkan dari BKKBN Provinsi Bengkulu telah mensosialisasikan dan membuat serta melauncing kampung KB di salah satu daerah Kecamatan Bang Haji. Namun, fakta di lapangan menunjukan hal berbeda yaitu masih dijumpai anak menikah di usia dini. Hasil penelitian Wahyuningrum et al., (2015) 
menyebutkan bahwa sebagian besar remaja dan orang tua tidak mengetahui terkait pendewasaan usia perkawinan.

Informan menyatakan takut kehilangan dan sangat mencintai pasangannya, ditambah lagi sudah ada ajakan dari pasangan untuk segera menikah. Untuk itu, informan tertarik membawa hubungan mereka ke jenjang pernikahan. Informan juga mengakui muncul perasaan cemas dan tegang ketika memutuskan menikah, karna nantinya akan menghadapi hidup yang baru bersama pasangan. Meskipun mereka pada akhirnya siap untuk menikah. Hasil penelitian Dariyo (2003) tentang motivasi menikah dini, cinta dan komitmen merupakan dasar utama pasangan untuk menikah. Banyak pasangan yang melangsungkan pernikahan karena memiliki kecocokan dan kesamaan minat. Secara psikologis, remaja cenderung berfikir secara singkat tanpa memikirkan dampak yang akan terjadi berikutnya.

Hasil penelitian menunjukan keputusan informan menikah di usia anak diambil karena tidak ingin mejadi beban akibat keadaan perekonomian keluarga, informan menyatakan tidak mengetahui tentang usia pernikahan yang baik untuk perempuan dan laki-laki, dan tidak mengatahui akibat yang ditimbulkan dari menikah usia dini. meskipun sudah dilakukannya sosialisasi dari pemerintah daerah maupun provinsi. Perasaan takut kehilangan dan mencintai pasangan juga mempengaruhi keputusan menikah di usia anak.

Evenhuis (2014) menyampaikan perempuan di daerah pedesaan dua kali lebih mungkin untuk menikah pada usia 18 tahun bila dibandingkan dengan perempuan di kota. Selain itu perempuan yang tidak sekolah tiga kali lebih mungkin untuk menikah bila dibandingkan dengan perempuan yang menempuh pendidikan sampai sekolah menengah. Anak yang menikah usia dini lebih cenderung memilih pasangan sendiri. Artinya, anak perempuan memilih untuk menikah karena alasan kompleks termasuk stigma seks pra nikah dan kehamilan.

Perkawinan usia kurang dai 18 tahun paling sering terjadi pada masyarakat patriarkal dimana orang tua memiliki peran penting dalam memilih pasangan untuk anak-anak mereka. Anak perempuan sering menikah tak lama setelah pubertas untuk memaksimalkan potensi melahirkan anak mereka. Banyak budaya memberi penekanan pada perempuan, yang sangat terkait dengan kehormatan keluarga. Orang tua dapat menikahkan seorang anak perempuan pada usia dini untuk memastikan bahwa dia menikah sebagai perawan dan untuk mencegah kelahiran di luar nikah (Council on Foreign Relation, 2013).

\section{Faktor Pemungkin}

Dari hasil penelitian menunjukan tersedianya sarana tempat hiburan yang dikunjungi informan untuk berkencan, informan menyatakan bahwasannya setiap malam ia bertemu dengan pacarnya, keluar pada malam hari bersama pasangan hingga larut malam baik itu hanya untuk jalan atau sekedar nongkrong-nongkrong di jembatan merupakan hal yang biasa dilakukan. Selain itu tempat hiburan yang dikunjungi untuk berkencan adalah saat ada pesta, acara muda-mudi saat ada pesta biasanya dilakukan pada malam hari. Menurut tokoh masyarakat setempat pergaulan anak di Kcematan Bang Haji ini terbilang bebas, karena banyak anak-anak yang berkeliaran pada malam hari, baik itu putra maupun putri.

Hasil penelitian menunjukan penggunaan handphone oleh informan lebih kepada media untuk berkomunikasi antara informan dengan pasangannya, didukung pula dari pernyataan tokoh masyarakat setempat menyatakan penggunaan handphone 
memperlancar komunikasi anak dengan orang-orang yang baru dikenalinya seperti perkenalan melalui media sosial facebook. Okfriana (2014) media komunikasi handphone dimanfaatkan untuk menjalin komunikasi dengan penyampaian rasa sayang "I love U" lewat media. Kecanggihan teknologi komunikasi dijadikan sebagai media untuk menjaga ikatan mereka

Norma sosial yang dirasakan mengenai pernikahan dini, keyakinan normatif dan manfaat yang dirasakan dari pernikahan tertunda setidaknya sama pentingnya dengan paparan komunikasi untuk mendukung hak anak perempuan untuk memilih pernikahan. Perbedaan gender dan pendidikan terdeteksi. Temuan menunjukkan bahwa program pencegahan perkawinan anak harus melakukan diversifikasi saluran informasi, memperkuat keuntungan yang dirasakan dari pernikahan yang tertunda, dan mengadopsi perspektif pengaruh sosial.

\section{Faktor Pendorong}

Hasil peneltian menunjukan orang tua dan lingkungan sosial dalam artian teman sebaya memilik peran terhadap pengambilan keputusan informan menikah usia anak sehingga menjadi terpengaruh karena melihat teman sebayanya sudah menikah. Munculah perasaan takut dari informan jika tidak segera menikah akan menjadi perawan tua. Di dorong pula keinginan orang tua yang ingin segera menimang cucu, padahal orang tua informan menyatakan jika menikahkan anaknya di usia muda maka akan menjadi bahan pembicaraan lingkungan sekitar dan berdampak pada ketidakharmonisan keluarga dikarenakan usia informan yang masih kecil sehingga rentan sekali tejadi keributan antara suami dan istri. Meskipun demikian orang tua memberikan dukungan kepada anak ketika anak memutuskan untuk menikah. Hal di atas yang menimbulkan keinginan informan untuk menikah menjadi bertambah kuat. Sejalan dengan hasil penelitian Khaparistia (2015) mengenai faktor-faktor penyebab terjadinya pernikahan usia muda menunjukan terjadinya perkawinan usia muda menunjukan remaja terpengaruh lingkungan sosial, dalam hal ini anak mengikuti teman sebayanya yang telah menikah usia muda.

Tidak terdapatnya peraturan daerah mengenai usia pernikahan. Hanya ada PERDA (Peraturan Daerah) yang mengatur wajib mengaji, jadi ketika ada pasangan yang mendaftarkan pernikahan di KUA setempat maka akan dites dari segi agamanya termasuk mengaji, apabila belum memenuhi syarat maka pihak KUA akan mengajarinya. Perda wajib mengaji juga sudah mulai diterapkan di sekolah-sekolah yang ada di Kecamatan Bang Haji melalui pendidikan TPA di sekolah.

\section{SIMPULAN}

Pernikahan usia anak terjadi disebabkan oleh terhentinya pendidikan, faktor ekonomi, tidak mau menjadi beban orang tua, kurangnya pengetahuan tentang dampak menikah di usia anak, serta tidak adanya aktifitas lain setelah putus sekolah. Handphone digunakan informan untuk menentukan jadwal pertemuan, selain itu adanya aktifitas di malam hari yaitu pasar malam yang memberikan peluang informan untuk berkencan. Keinginan orang tua menimang cucu, melihat teman sebaya sudah mempunyai anak dan tidak adanya peraturan khusus tentang pernikahan usia anak mendorong informan untuk menikah. 


\section{SARAN}

Perlu adanya kerjasama antara KUA, Dinas Kesehatan, Dinas Pendidikan untuk melakukan pendampingan kepada keluarga calon remaja dan remaja untuk mencegah pernikahan usia dini. Selain itu perlunya keaktifan dari tokoh masyarakat dalam mengontrol perilaku remaja di desa.

\section{DAFTAR PUSTAKA}

BKKBN Prov Bengkulu. (2017). Tingginya Angka Menikah Dini BKKBN Gelar Workshop Genre diakses dari http://bengkulu.bkkbn.go.id/Lists/Berita/DispForm.aspx?ID=1736\&ContentTyp eId=0x0100A28EFCBF520B364387716414DEECEB1E

BKKBN. (2012). Survey Demografi dan Kesehatan Indonesia Tahun 2012. Jakarta: $\mathrm{BKKBN}$

BPS. (2015). Kemajuan yang Tertunda: Analisis Data Perkawinan Usia Anak di Indonesia. Jakarta: BPS

Council on Foreign Relation. (2013). Child Marriage. Diakses dari https://www.cfr.org/peace-conflict-and-human-rights/childmarriage/p32096\#!/?cid=otr_marketing_use-child_marriage_Infoguide\#!\%2F

Dariyo, A. (2003). Psikologi Perkembangan Dewasa Muda. Jakarta: PT.Gramedia Widiasarana

Evenhuis, M. J. (2014). Just Married, Just a Child: Child Marriage in the Indonesian Pacific Region. Melbourne: Plan International Australia

Hotchkiss, D. R.. Godha, D. G., Anastasia, J., \& Cappa, C. (2016). Risk Factors Associated with the Practice of Child Marriage among Roma Girls in Serbia. BMC International Health and Human Rights 16:6 DOI 10.1186/s12914-0160081-3

Kemenkes. (2010). Riset Kesehatan Dasar Indonesia 2010. Jakarta: Kemenkes

Kemenkes. (2012). Survei Dasar Ksehatan Indonesia. Jakarta

Khaparistia, E. W. (2015). Faktor-Faktor Penyebab Terjadinya Pernikahan Usia Muda (Studi Kasus di Kelurahan Sawit Seberang Kecamatan Sawit Seberang Kabupaten Langkat). Jurnal Ilmu Kesejahteraan Sosial, 14 (1)

Okfriana, R. (2017). Pola Komunikasi Pasangan yang Menjalani Hubungan Pacaran Jarak Jauh. Universitas Negeri Semarang

Wahyuningrum, D. M., Gani, H. A., \& Ririanty, M. (2015). Upaya Promosi Kesehatan Pendewasaan Usia Perkawinan oleh Pusat Informasi Konseling Remaja (PIK-R) Ditinjau dari Teori Precede-Proceed. e-Jurnal Pustaka Kesehatan, 3(1), 186192. https://jurnal.unej.ac.id/index.php/JPK/article/view/2682 